\title{
Faremelding: Understrømmer
}

Etter stortingsvalget i 2009 skrev jeg en leder med tittelen Exit (1). Jeg uttrykte bekymring over at de høylytte protestene mot stadig mer uklare og uforklarlige omorganiseringer i spesialisthelsetjenesten hadde stilnet og over at mange av våre beste kolleger ikke lenger ville utsette seg for å bli upopulære - eventuelt oppsagt ved å målbære sine motforestillinger. Tittelen viste til Albert Hirschmans bok Exit, voice and loyalty: responses to decline in firms, organizations and states (2). Hovedpoenget er at medlemmer av en organisasjon - enten det er et privat firma, et land eller en hvilken som helst annen gruppering - bare har to alternativer når de ser organisasjonen forvitre og kvaliteten forringes. De kan enten trekke seg ut (exit) eller de kan søke å forbedre organisasjonen ved å komme frem med sin misnøye og sine forslag til endringer (voice). Høy «exit», enten ved at folk forlater organisasjonen eller ved at de slutter å engasjere seg, er et faresignal.

Jeg har aldri skjult min skepsis til premissene for og gjennomføringen av foretaksreformen i spesialisthelsetjenesten og har kommentert dette fortløpende fra den ble vedtatt i juni 2001 (3-6). Det har flere gjort (7-11), men i forhold til ressursene som er brukt på organisasjonsendringer i spesialisthelsetjenesten de siste ti årene, har det vært overraskende vanskelig å få aktørene selv til å skrive (12). De fleste tilbakemeldinger har jeg fått på e-post og i fortrolige samtaler med faglig dedikerte kolleger som er stadig mer fortvilet og frustrert over det som skjer med den offentlige helsetjenesten i Norge, som de har vært så stolte av. Men aldri har jeg fătt så mange tilbakemeldinger som da jeg i Tidsskriftet nr. 17/2010 beskrev språkbruken man i Helse Sør-Øst og Oslo universitetssykehus anvender for å få gjennomført sitt store prosjekt i hovedstaden (13).

En leser var sterkt kritisk til lederen og mente jeg brukte Tidsskriftet som internavis for Oslo universitetssykehus og hadde oversett en artikkel om effekten av sammenslåing av sykehus, publisert tidligere $\mathrm{i}$ år. Jeg kunne godt nevnt denne litteraturgjennomgangen (14), men også den viste at det er vanskelig å få til besparelser (eventuelle ulemper for pasientene var ikke nevnt). Bare under helt bestemte forutsetninger kunne man oppnå en moderat kostnadsreduksjon: ved sammenslåing av noen få like store sykehus med under 200 senger i sykehusmarkeder med sterk konkurranse - altså i områder med overkapasitet (les: enkelte steder i USA). Og sykehusene måtte ikke bli for store: Kostnaden per behandlet pasient øker når sengetallet passerer 600 (15). Ingen av disse forutsetningene ser ut til å være til stede i Oslo.

Tilbakemeldingene på lederen fra det store flertall av kolleger har, dessverre, bare økt min uro for at dette bærer helt galt av sted. Noen må trekke i nødbremsen! Dette er noe langt mer enn en lokal Oslosak. Jeg vil derfor dele enkelte av tilbakemeldingene, lett omskrevet for at ikke avsender skal kunne identifiseres - siden denne debatten ikke med selvfølge kan tas i full åpenhet. De taler for seg selv, og de taler tydelig. Her er tre eksempler:

Siste leder går rett til kjernen av virkeligheten slik den fremstår på et kontor i Oslo universitetssykehus. Legger ved siste nyhetsbrev som ikke svikter, spesielt liker jeg setningen «God linjekommunikasjon både nå og i tiden etter 13. september er helt avgjørende for at vi skal lykkes». Jeg skjønner overhodet ikke hva det betyr i praksis!!
Tror imidlertid ikke legenes maktesløshet stilt overfor uklare tulleformuleringer gir makt til de som sitter lenger opp i systemet. Derimot forer det til som du helt riktig skriver at «ncere ting» blir viktigere. Når man helt mister eierskapet til avdelingen, er det ikke lenger noen som bryr seg om å bidra til økonomistyring, det blir vakansvakter over en lav sko og bruk av dyrt utstyr som ikke er nødvendig - men morsomt. Dette gjør at INGEN lenger har makt eller styring, og det er i alle fall ikke bra for fremtidens pasienter.

Det er jo også interessant hvor lukket, og egentlig diktaturncert, hele denne store OUS-organisasjonen etter hvert blir med sin enøyde pukking på «linjen», som egentlig demper og tilslører problematisk informasjon på vei fra leger og pasienter til «toppen», og hvordan reelt problematiske saker som for eksempel dyktige klinikksjefers avgang dysses ned med noen «omforente» formuleringer om "enighet», "kommet til», "etter en totalvurdering» etc., etc. Sannheten er jo at det dessverre er svaert få «believers» igjen blant oss som arbeider med pasienter.

Hvorfor er det ingen som sier fra om det som skjer - at vi f.eks. betaler husleie for tomme lokaler $i$ Akersbakken $i$ to år mens vi flytter hjertesenteret opp på Gaustad, raserer Barnesenteret for à tømme Aker etc., etc. Hvor er vinningen? Hva koster dette? Er vi bare lojale? Er vi redde?

Ja, hvorfor er det ikke noen som sier ifra? Eller mer presist: Hvorfor når ikke bekymringsmeldingene frem til beslutningstakerne? For uroen og følelsen av avmakt hos dem som har bygd opp og drevet behandlingstilbudene er ikke ny. Likevel berømmer styret i Helse Sør-Øst administrasjonen og helseforetakene for å ha sikret bredt engasjement og nødvendig forankring og medvirkning (enstemmig vedtak, sak 108-2008)! Og administrerende direktør for Helse SørØst Bente Mikkelsen er ikke bekymret. Da hun ble spurt av Dagens Næringsliv 17. august 2010 om hvordan hun så på at de ansattes tillit til direktøren ved Oslo universitetssykehus var tynnslitt, svarte hun: «Mitt inntrykk er at det er en veldig god dialog mellom Hatlen og de ansatte. Det er i grunnen svaret. Hatlen er kjent for tett, god dialog, og de tillitsvalgte synes de blir godt behandlet, slik jeg oppfatter det» (16).

Det er umulig å stanse Oslo-prosessen nå, sies det. Mon det? De fire som leder an - Hatlen, Harlem, Mikkelsen og Strøm-Erichsen har makt til å gjøre det. Så det er et spørsmål om vilje.

Mikkelsen har tidligere vist at hun ikke synes det er noen skam å snu. I 2003 uttalte hun f.eks. til Aftenposten at «Spekulasjonene om at Helse Øst har en langsiktig plan om å legge ned Aker universitetssykehus, stemmer absolutt ikke. Vi skal utvide kapasiteten og gjøre sykehuset større enn i dag» (17). Mot den pågående Oslo-prosessen er det sterke understrømmer, så sterke at man bør ta hensyn til dem.

\section{Charlotte Haug}

redaktør

Litteraturlisten finnes i lederen på www.tidsskriftet.no 